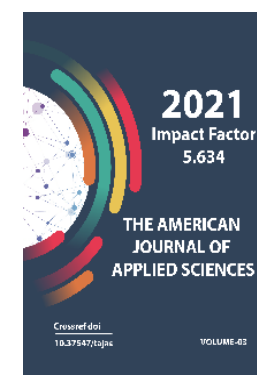

\title{
On The Basis Of An Integrated Approach, Give Environmental Education To Primary School Students
}

\author{
Musurmonova Shahlo-Ilhomovna \\ Doctoral Student Of Gulistan State University, Uzbekistan
}

\begin{abstract}
Journal Website: http://theamericanjour nals.com/index.php/taj as

Copyright: Original content from this work may be used under the terms of the creative commons attributes 4.0 licence.
\end{abstract}

\section{ABSTRACT}

The article highlights the environmental education of Primary School students on the basis of an integrated approach,their contribution to the comprehensive formation of environmental etiquette, the Prevention of pollution of water, soil, air, the preservation of the colorfulness of plants and animals, the negative consequences of the actions committed to nature.

\section{KEYWORDS}

Integration, environmental education, environmental Environment, Environmental etiquette, water, soil, air, plant, animal, environment.

\section{INTRODUCTION}

Today, science and technology are developing at an accelerated pace, causing great damage to the environment due to the fact that the natural balance between man and nature is being maintained, care for nature in members of society has become stagnant.

Our President Sh.As Mirziyoyev noted, the decision on an integrated approach in educational work, i.e. a collaborative and targeted approach, is being tightened. The need for systematic work, combining the forces and opportunities of state and public organizations, first of all the Youth Union of Uzbekistan in spiritual and educational activity, is determined in the priority task.

Especially in the formation of the concepts of environmental safety of Primary School students, the formation of an ecological culture in the minds of the students first of all is an extremely topical treatment. 
Culture- (Arabic "culture"-Medina, urban; education-upbringing)-there are material, spiritual riches created by people in the process of mastering and changing nature, existence, as well as ways and methods of restoring and building these riches. The socalled "culture" came from the name of the city of Medina, where Muslims were respected, because the first Muslims received education mainly in Medina. Culture is a wide coverage event related to material and spiritual production, social and mutual relations, politics, family, morality, manners, rights, education, upbringing, creativity, science, service, lifestyle etc.

Thus, culture is considered a complex of all positive achievements accumulated in the process of the activity of society and its citizens, a high indicator of the activity of a person.

The theory of integration is formed in connection with and due to the development of theories of integrity and systematization. Systematism found content as a holistic approach to the objects of the study - it first began to understand holistic (integrity), then developed and clarified in the concepts of system and organization. Within these categories, the ever-increasing number is considered whole. This situation is timely g.Hegel also pointed out that the attitude of the whole and the part is dead, mechanical aggregate, although it has certain forms, for this reason, its independent matter variety is proportional to a certain unit, but it is to them that it is in this way that this unit will continue to be an exception to diversity.
In the Explanatory Dictionary of the Uzbek language "integration (lot. integratio) restore, restart, fill.

1. A concept that expresses the state of the bonding of individual parts, elements, combining them together.

2. The process of convergence and interconnection of Sciences.

3. Mutual coordination and unification of the population of two or more states", "integral (lot. integer - a whole, intact, restored) - mat. In higher mathematics, the whole quantity, which is considered as the sum of infinite small numbers. Integration-mat. find the Integral of a given function, a mathematical expression, determine"quot;.

In integrated education-it is learned to deepen and increase sciencelararo knowledge (integrated knowledge), to form them.

Integrative education is formed on the basis of the basic sciences that cover each section of modern knowledge. Among them are pedagogics, pedagogical technology, pedagogical psychology, psychology of human age, pedagogical psychology studying the process of science development, studying the dependence of science on other life processes of a person: cybernetics management, communication and processing of Information: Science Informatics studying the structure and properties of Information, its place in the formation of a person. Application of synergetics, studying the relationship of systems with scientific direction in various processes of human life. The content of integrated education in this class is based on the meaning and structure of these subjects. 
Environmental education for Primary School students is not an educational activity carried out through educational activities in akhyon. Until now, our schools have done a lot of commendable work on advanced and effective forms, methods and tools of environmental education, creation and application of content to students.

One of the most urgent problems of the present day is the development of various measures to accelerate the protection of nature on the basis of achievements of Science and technology by increasing knowledge of environmental education and culture among different sections of the population. The fundamental meaning of environmental education and upbringing is the study of natural and social laws, which are a constant unity between nature and society and link them to each other, an indicator of their application to life.

Ecological education-this is an expression from mastering the structure, development, transformation of living nature, the state of living things on earth, the relationships between each other and the environment, the number and quality of Natural Resources, their types, as well as ways of their conservation and conservation.

Ecological education and upbringing is an expression from the moment a person steps into nature, motivates him to consciously use nature throughout his / her life, to develop the traditions, customs, traditions of our people with respect and attention to nature, to multiply natural riches, to organize gardeners, flowerbeds, to evoke good qualities in his / her soul.
Environmental education is an important direction in pedagogy. Environmental education-is the training in the process of giving the reader-youth a system of knowledge that expresses the relationship between nature and man. Environmental education is the education of the reader-the conscious attitude of young people towards the world around us, the environment.

Environmental education, by reflecting human and natural relations in the life-forms, performs the task of educating the human personality, along with the expression of the level and world outlook of the ecological and cultural level of young people. After all, every age should only be mature and harmonious, at the same time be in a fair attitude to the environment, and if nature perceives its laws as its own internal experiences, that is, it can literally achieve a high level of spirituality and culture, if it works in harmony with nature, harmoniously.

Hence, from this it is possible to express the meaning and essence of environmental education as follows, that is, it is one of the main and components of general education and education, with the help of which the formation of a conscious attitude towards the environment and solutions to its problems in the reader-youth, as well as armed them with knowledge, skills and

And the main goal of environmental education is to form a conscious attitude towards the environment and its problems in the readeryouth, as well as knowledge, skills and skills of finding optimal solutions to them. To accomplish this goal, it is necessary to solve a number of tasks. 
1. The reader is to teach our young people to investigate and consciously protect their place of residence (nature) and their wealth in the provision of ecological education.

2. Formation of ecological culture. It is necessary, first of all, to start with the family.

3. Formation of environmental literacy. It is desirable that the reader-young people used life examples in teaching.

4. To give the reader-young people knowledge about the concepts and legalities of Ecology. In this, attention is paid to the concepts and laws of labor protection, conservation of nature, the list of rare creatures, the Prevention of crises in nature and the atmosphere.

Since the future of our country is in the hands of the younger generations, educating them as mature, humane, responsible persons before society and nature in all respects is one of our priority goals. During a short period of time since our independence, there have been great socio-political and economic changes in the history of our people and state. The history of our centuries-old incomparable spiritual heritage has re-established our culture, religion and language. At the heart of our youth in educational institutions of all types are given the national pride, the content of environmental culture toptirishga serious importance. In this regard, the possibility of natural science, especially studied in primary classes, can not be overestimated. Because of the rich nature of our homeland, various erosion and surface riches, the creative work carried out by our people, the growing prestige and prestige of the Uzbek people among the inhabitants of the land sphere are the means of content, provision of national pride in the readers.

Training is planned, in a particular system, depending on the cognitive activity, depending on the content of the training material and its coverage with didactic activities, methods and forms of teaching. Such education is achieved by the fact that the whole pedagogical activity is aimed at. The teacher can take advantage of the opportunities of comprehensive education in the process of teaching Natural Science.

So, one of the goals of the ecological education of the reader-youth is to keep our sacred Mother Land, the sky of sorrow as tidy as it was. This is a great contribution to the prosperity of our native land, with the help of which human qualities such as prosperity and chastity, purity and saving, evangelism and gentleness are formed in the schoolchildrenyoung people. These are the concepts of nature in the reader-youth, the natural environment, the connection between natural factors and them, the use of natural resources to save and protect them, the preservation of the environment from pollution, the desire to leave nature as it were for future generations, etc.form.

\section{REFERENCES}

1. Sh.M. Mirziyoev is pursuing rapid development and renewal on the basis of the strategy of actions Tashkent-2017. Twenty-six P.

2. M.Abdullaeva, M.Abdullaeva., G.Abdurazzakova and others. Independence / / annotated scientificpopular dictionary. - T.: East, 1998. 
3. Sobirovna, T. R. (2021). Issues of further improvement of water cadastre legislation of Uzbekistan. ACADEMICIA: An International Multidisciplinary Research Journal, 11(4), 1241-1253.

4. Explanatory Dictionary of the Uzbek language. "National Encyclopedia of Uzbekistan". State Scientific Publishing House, - T.: 2006. 3 volumes. - 557 b.

5. A.V. Malev Basic principles of integration of educational programs in the system of training a foreign language teacher / A.V. Malev / / Problems of modern didactics: Collection of scientific articles. Issue 3. Smolensk, GOUVPO, 2004. - p. 68 -73 b. 